\title{
Acute and Sub-Acute Toxicological Evaluations of Bioactive Alkaloidal Extract from Melodinus henryi and Their Main Chemical Constituents
}

\author{
Meilian Yang ${ }^{1} \cdot$ Yudan Wang ${ }^{1,2}$. Zhifeng Fan ${ }^{1}$ - Qingwang Xue ${ }^{3}$ Guy Sedar Singor Njateng ${ }^{4} \cdot$ Yaping Liu $^{1,4}$. \\ Jianxin $\mathrm{Cao}^{1} \cdot$ Tianrui Zhao $^{1}$. Guiguang Cheng ${ }^{1}$ (I)
}

Received: 13 May 2020 / Accepted: 4 June 2020 / Published online: 9 June 2020

(c) The Author(s) 2020

\begin{abstract}
Melodinus henryi is a good source of terpenoid indole alkaloids, and traditionally used as a folk medicine in the treatment of meningitis and fracture. In order to further exploit their potential uses, its anti-inflammatory and immunosuppressive activities, safety evaluations and chemical profiles have been illustrated. Compared to the crude methanol extract from $M$. henryi and its non-alkaloidal fraction, the total alkaloidal fraction (MHTA) had the strongest anti-inflammatory and immunosuppressive activities. In the acute oral toxicity assay, the half lethal dose $\left(\mathrm{LD}_{50}\right)$ of MHTA was more than $2000 \mathrm{mg} / \mathrm{kg}$. The sub-acute toxicity assay for consecutive 28 days exhibited MHTA at a lower concentrations of less than $500 \mathrm{mg} / \mathrm{kg}$ might be regarded as safe, and might damage spleen, liver, kidney, and heart when the dose is higher than $1000 \mathrm{mg} / \mathrm{kg}$. In addition, a phytochemical investigation on MHTA led to the isolation of 15 monoterpenoid indole alkaloids. Thus, in regard with the potent side effects of MHTA, it should be used with caution in the development of phytomedicine.
\end{abstract}

Meilian Yang and Yudan Wang have contributed equally to this work.

Tianrui Zhao

food363@163.com

Guiguang Cheng

chengguiguang@163.com

1 Faculty of Agriculture and Food, Kunming University of Science and Technology, Kunming 650500, People's Republic of China

2 Engineering Research Center of Biopolymer Functional Materials of Yunnan, Yunnan Minzu University, Kunming 650500, People's Republic of China

3 Department of Chemistry, Liaocheng University, Liaocheng 252059, Shandong, China

$4 \quad$ State Key Laboratory of Phytochemistry and Plant Resources in West China, Kunming Institute of Botany, Chinese Academy of Sciences, Kunming 650204, People's Republic of China 


\section{Graphic Abstract}

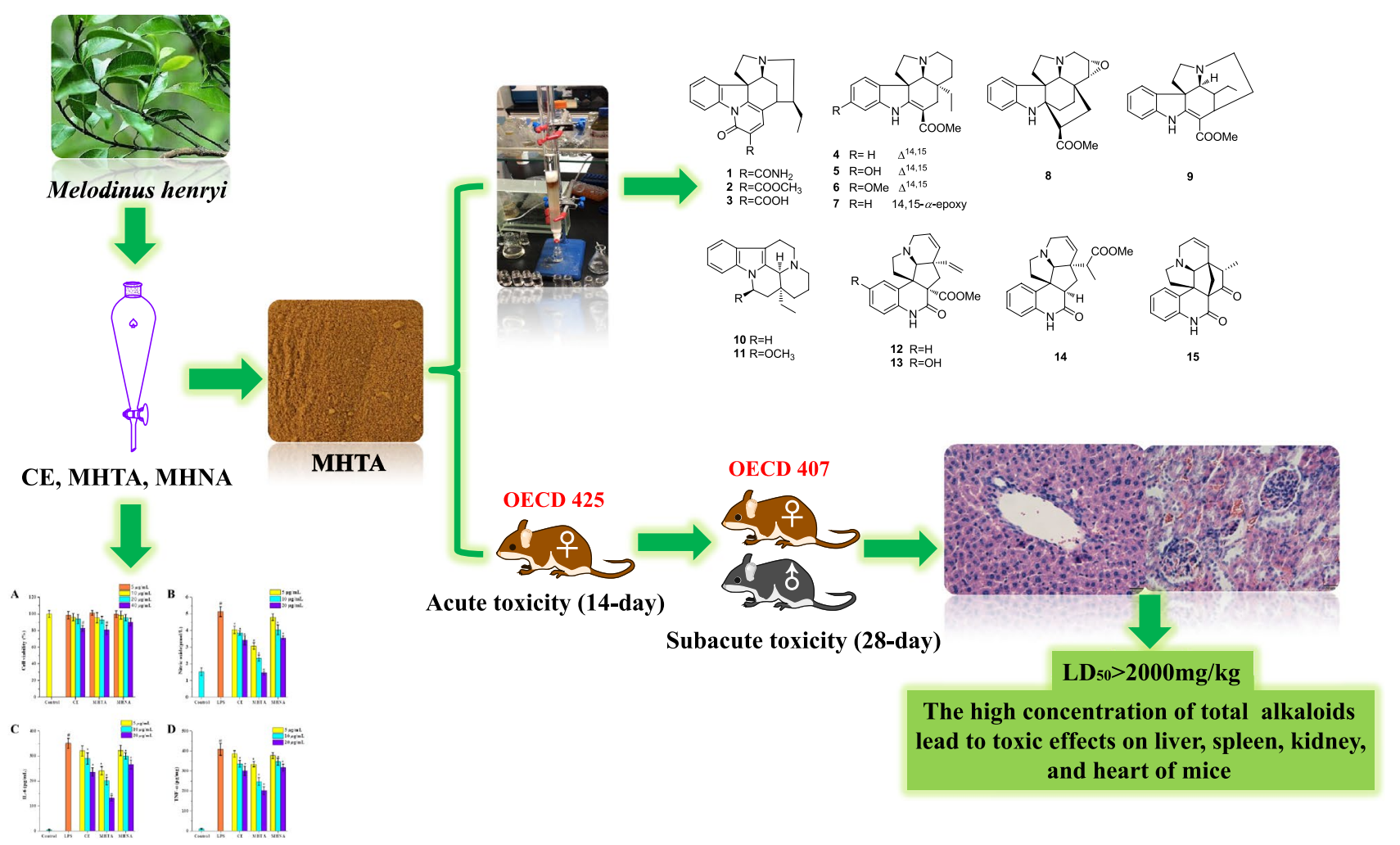

Keywords Melodinus henryi $\cdot$ Acute toxicity $\cdot$ Subacute toxicity $\cdot$ Monoterpenoid indole alkaloids

\section{Introduction}

Medicinal plants have a long history in the prevention and treatment of human various diseases due to their health promoting potentials [1]. The natural products from medicinal plants are an important productive drug source for providing molecular scaffolds in the modern drug discovery research $[2,3]$. Alkaloid is one of the most important classes of plant natural products with a large range of therapeutic properties, including anti-depressant, immunosuppressive, antimicrobial, anti-inflammatory, anti-tumor, etc. [4-6]. Some of which have been developed as clinical drugs to treat a variety of illnesses [7].

Plants of the genus Melodinus (Apocynaceae) are rich in terpenoid indole alkaloids (TIAs) and widely distributed in the tropical and sub-tropical regions [8]. Among them, $M$. henryi is a perennial vine mainly distributed in China, Thailand, and Burma [9] and has been used as a folk medicine for the treatment of infantile meningitis and fractures [9]. Phytochemical studies have revealed that the stems, bark, leaves, and fruits of $M$. henryi present a series of structurally novel TIAs in the meric and dimeric forms, such as melodinines A-G [10] and V [11], melodinines X1-X4 [12] and W1-W4 [13], melohenines A and B [14], melodinhenines A-F, henrycinols A and B $[15,16]$. Some of them were characterized with complex polycyclic skeletons and some alkaloids have significant biological potentials, especially the cytotoxic activity $[10,11,17]$.

Previous studies of this plant are mainly focused on the discovery of TIAs with novel structures, and significant cytotoxic activity. However, the information of bioactive components responsible for the treatment of inflammatory diseases remains unclear. In order to further exploit its potential uses, it is necessary to illustrate the bioactive extract, evaluate its toxicity, investigate its chemical constituents. Thus, the obtained total alkaloidal extract (MHTA) and non-alkaloidal extract (MHNA) from $M$. henryi were evaluated their biological activities. Furthermore, the toxicological evaluations of MHTA were performed by assessing acute and sub-acute toxicities in vivo. The chemical constituents of MHTA were carried out by column chromatographic methods and identified by a combination with NMR and MS analysis. 


\section{Results}

\subsection{The Anti-Inflammatory Effects of Different Extracts from $M$. henryi}

The anti-inflammatory activity was performed in LPSinduced RAW264.7 macrophages as previously described method [18]. Firstly, the CE, MHTA and MHNA were evaluated their cytotoxic effects on the RAW264.7 cells. The cell viability results revealed that all the samples were of no toxic at the concentrations of $5-20 \mu \mathrm{g} / \mathrm{mL}$ (Fig. 1a). Thus, the anti-inflammatory effect of CE, MHTA and MHNA were investigated and the results were showed in Fig. 1b-d. As showed in Fig. 1b, the productions of NO increased by treating with LPS, and dose-dependently decreased by different extracts of $M$. henryi. Among them, the MHTA showed the highest inhibition of nitric oxide release (Fig. 1b). In addition, all the different extracts of $M$. henryi remarkably inhibited the levels of IL- 6 and TNF- $\alpha$ compared to the LPS induced group. In particular, the MHTA showed the highest inhibitory effect on the products of pro-inflammatory cytokines.
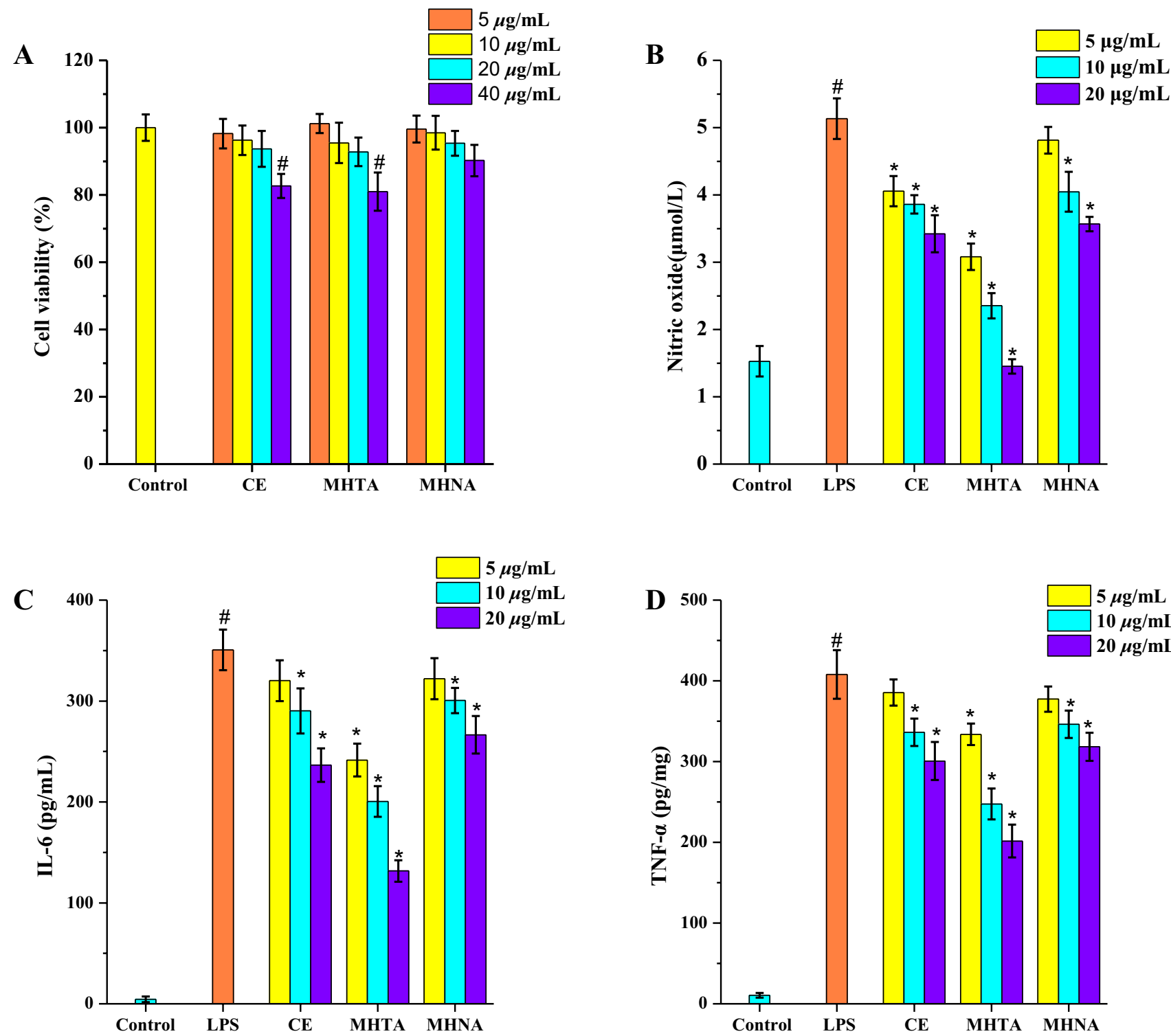

Fig. 1 a Effects of CE, MHTA and MHNA on the viability of RAW264.7 cells; b effects of CE, MHTA and MHNA on nitric oxide production of RAW264.7 cells; The effects of CE, MHTA and MHNA on inflammatory cytokines of RAW264.7 cells, c IL-6; D:

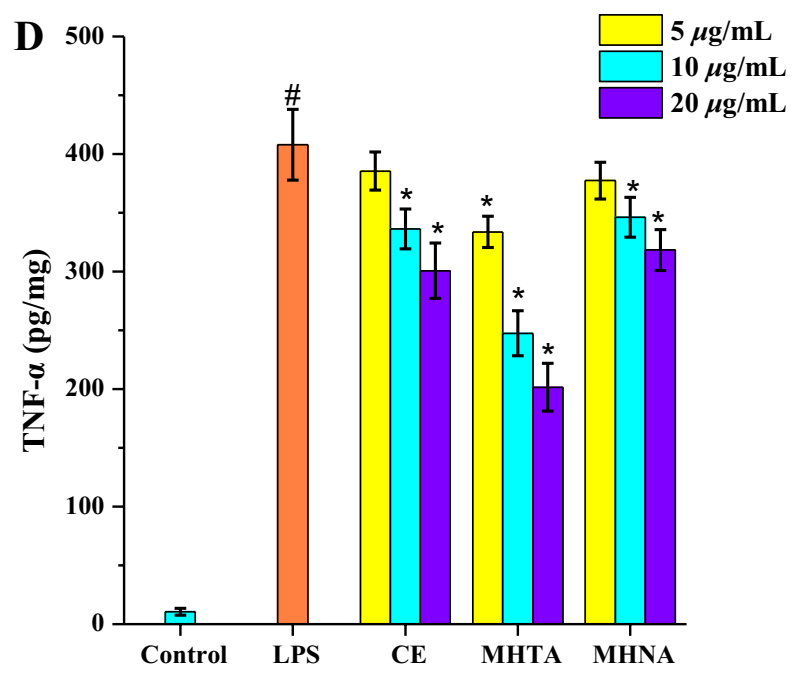

TNF- $\alpha$. Data represent mean $\pm \mathrm{SD}, n=3 .{ }^{\#} p<0.05$, means significant difference from the control group. ${ }^{*} p<0.05$, means significant difference from the LPS group 


\subsection{The Immunosuppressive Activity of Different Extracts from $M$. henryi}

The immunosuppressive activity of CE, MHTA and MHNA were evaluated on mitogen-stimulated mice splenocyte proliferation with dexamethasone (DXM) as a positive control. As showed in Fig. 2a, b, different extracts of M. henryi significantly inhibited Con A-/LPS-stimulated mice splenocytes proliferation in a dose-dependent manner. Among them, MHTA showed the strongest inhibitory effect, comparable to the efficacy of DXM at a concentration of $20 \mu \mathrm{g} / \mathrm{mL}$.

\subsection{Acute Toxicity Study}

In the acute toxicity, oral administration of MHTA revealed no treatment-related mortality at a single dose $(0,300,1000$ and $2000 \mathrm{mg} / \mathrm{kg}$ ). The food and water intakes and weight gain decreased slightly with no significant difference $(p>0.05)$ when compared to those of the control group (Table 1). The organ coefficients of body organs are shown in Table 2, and there were no significant variations among treated and control groups. Macroscopic examination of liver, kidneys, heart, and spleen did not reveal any changes. Therefore, the $\mathrm{LD}_{50}$ of MHTA was considered to be higher than $2000 \mathrm{mg} / \mathrm{kg}$.

\subsection{Sub-Acute Toxicity Study}

\subsubsection{Body Weight, Food and Water Intake}

During the 28 days of MHTA treatment, no treatment related toxicity signs or other behavioral and physiological changes were found in both sexes of control and treated animals at MHTA doses of 125, 250 and $500 \mathrm{mg} / \mathrm{kg}$. However, irregular hair in the mice treated with the highest dose was observed at 2 nd week. As shown in Table 1, the body weight of 125 and $250 \mathrm{mg} / \mathrm{kg}$ MHTA treated animals increased continuously, as did the control group. However, in the 500 and $1000 \mathrm{mg} / \mathrm{kg}$ groups, the weight gains of animals decreased significantly. At the end of experiment, the body weight, food intake and water consumption of animals in the groups of $1000 \mathrm{mg} / \mathrm{kg}$ were significant lower than those in the control group $(p<0.05)$, whereas a similar phenomenon was observed at $500 \mathrm{mg} / \mathrm{kg}$ group but was not significant $(p>0.05)$ (Table 1).

\subsubsection{Organ Coefficient}

The organs of all animals were collected and weighted after the experiment, and the relative organ coefficients were calculated as shown in Table 2. No significant differences occurred in organ coefficients (heart, spleen, lung, kidney, testis and ovary) between treated and control groups. However, the relative liver coefficient in both males and females treated with $1000 \mathrm{mg} / \mathrm{kg}$ MHTA markedly increased compared to that in mice of the control group $(p<0.05)$.

\subsubsection{Hematological Analysis}

The hematological parameters in animals are shown in Table 3. In both female and male mice, the WBC and LYM levels significantly increased in the groups of 500 and $1000 \mathrm{mg} / \mathrm{kg}$ MHTA in comparison with the control

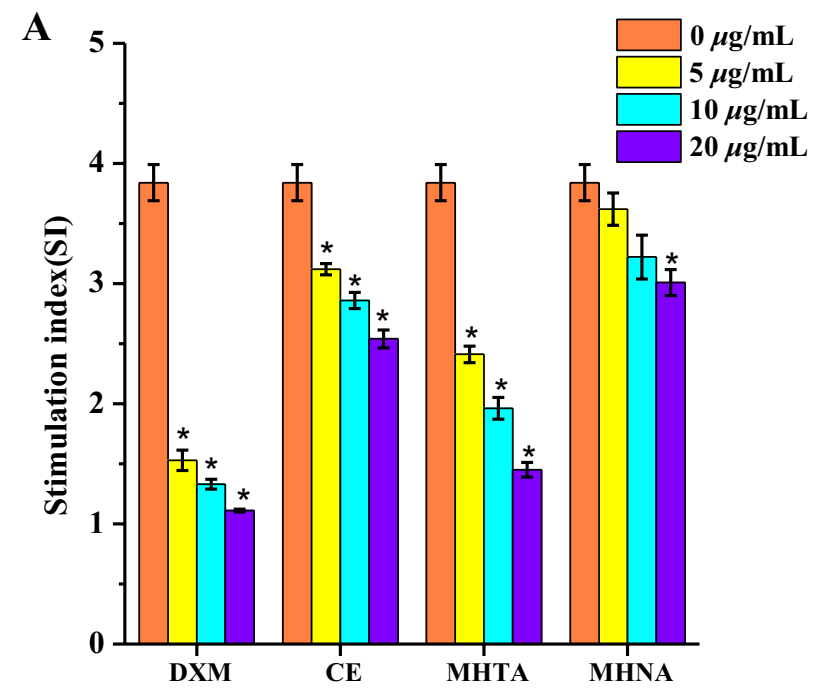

Fig. 2 Inhibitory effects of CE, MHTA and MHNA on Con A-stimulated T lymphocyte proliferation (a) and LPS-stimulated B lymphocyte proliferation (b) in vitro. DXM was used as a positive con-

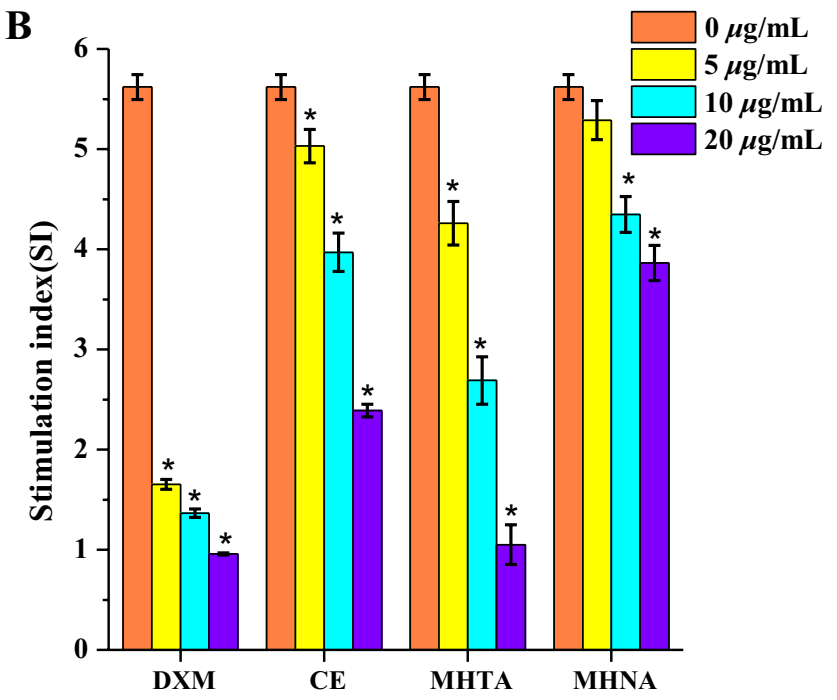

trol. The values are presented as mean \pm SD of triplicates. ${ }^{*} p<0.05$, means significant difference from the control group $(0 \mu \mathrm{g} / \mathrm{mL})$ 


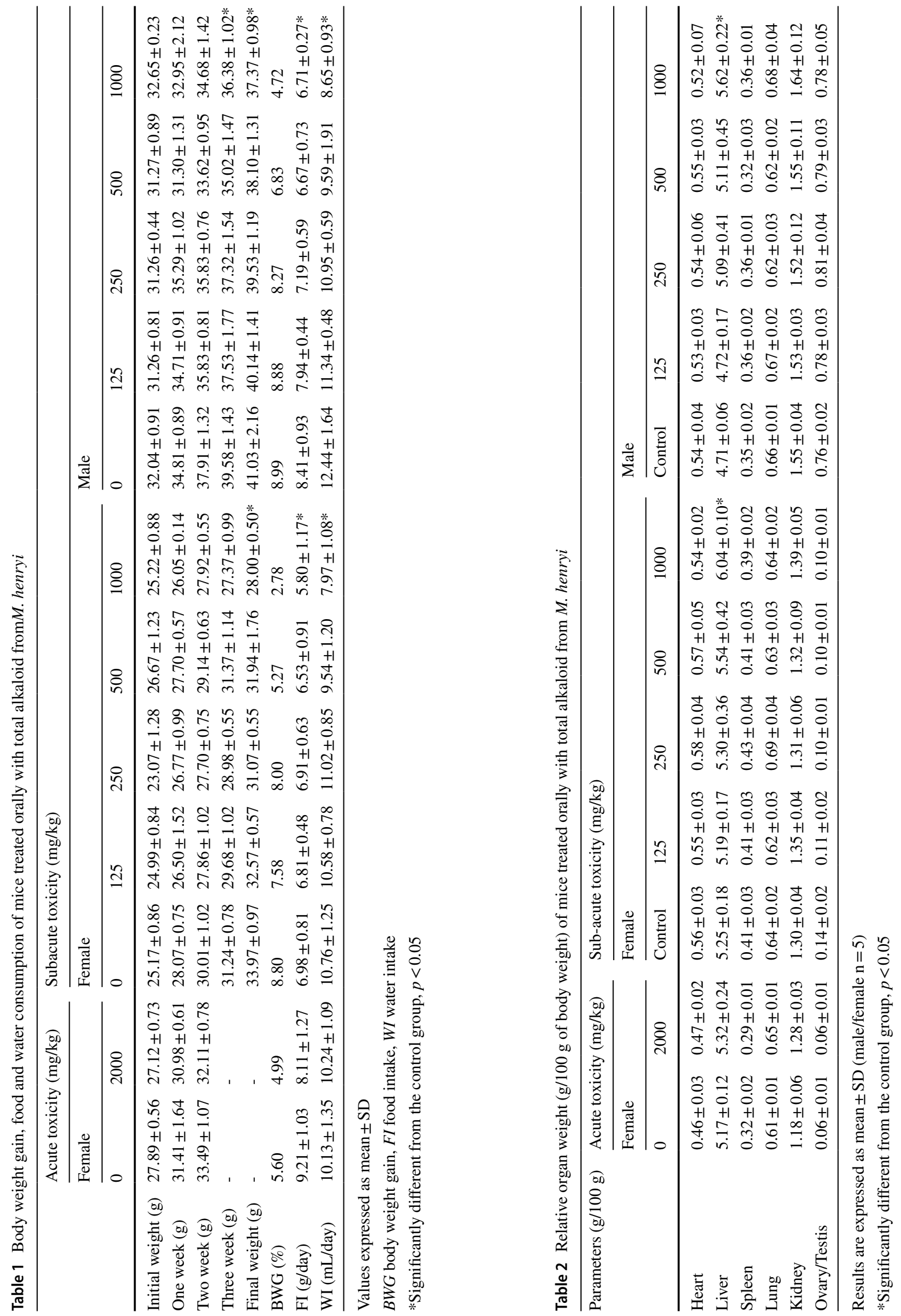




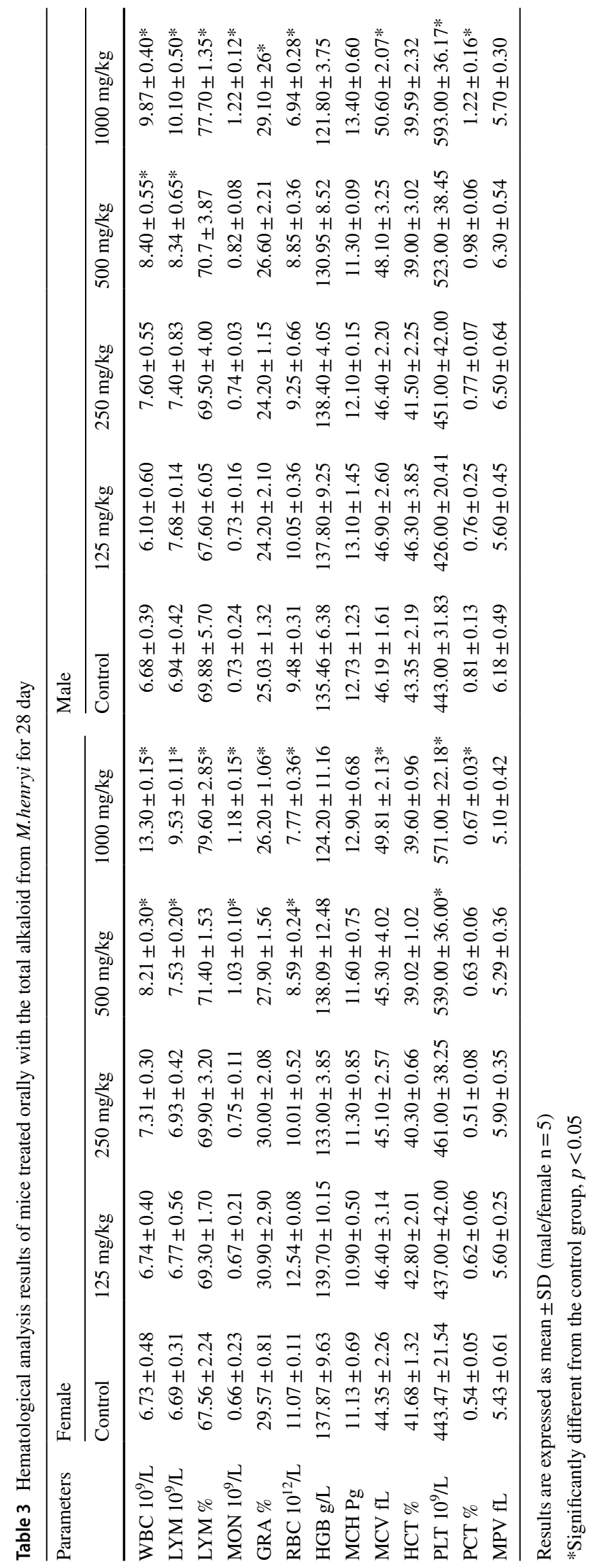


ones $(p<0.05)$. Besides, the LYM\% and MON in females treated with $500 \mathrm{mg} / \mathrm{kg}$ MHTA as well as males and females that received $1000 \mathrm{mg} / \mathrm{kg}$ MHTA were obviously increased $(p<0.05)$ than those in mice of the control group, The GRA\% and RBC significantly decreased in mice of $1000 \mathrm{mg} / \mathrm{kg}$ (both sexes) and RBC also significantly decreased in females of $500 \mathrm{mg} / \mathrm{kg}(p<0.05)$. The MCV levels in $1000 \mathrm{mg} / \mathrm{kg}$ MHTA significantly increased than the control group. PLT levels significantly increased in females at dose of $500 \mathrm{mg} / \mathrm{kg}$ and all animals at dose of $1000 \mathrm{mg} /$ $\mathrm{kg}$, while PCT\% significantly increased in the $1000 \mathrm{mg} / \mathrm{kg}$ MHTA group $(p<0.05)$. In addition, no significant changes were observed in other biochemical parameters between the control and MHTA treated mice.

\subsubsection{Serum Biochemical Parameters}

In sub-acute toxicity, the serum biochemical parameters are summarized in Table 4. Both female and male mice treated with 500 and $1000 \mathrm{mg} / \mathrm{kg}$ MHTA exhibited a remarkable decrease in TP in comparison with control $(p<0.05)$. Meanwhile, ALB levels were significantly decreased in males treated with 500 and $1000 \mathrm{mg} / \mathrm{kg}$ MHTA $(p<0.05)$, and that in females were also decreased with no statistical significance. The levels of AST in $1000 \mathrm{mg} / \mathrm{kg}$ MHTA group and ALT, BUN and CRE in 500 and $1000 \mathrm{mg} / \mathrm{kg}$ MHTA groups significantly increased $(p<0.05)$ compared to the control group. Na concentrations in females treated with $1000 \mathrm{mg} /$ $\mathrm{kg}$ MHTA statistically decreased $(p<0.05)$, while $\mathrm{K}$ values markedly increased (both females and males) $(p<0.05)$ in comparison with the control ones. Moreover, the parameters such asTBIL, TG, TC, GLU and $\mathrm{Cl}$ were found in a normal range with no significant difference to the control.

\subsubsection{Histopathological Analysis}

The histopathological studies of the vital organs (kidney, liver, heart, spleen, lungs, ovary, and testis) of the control group, 125 and $1000 \mathrm{mg} / \mathrm{kg}$ MHTA groups were performed. The photomicrograph results of those vital organs were as follows: for liver parenchyma, normal morphology of hepatic lobules were observed in the control (Fig. 3A1) and lowest dose group (Fig. 3A2), while tissue necrosis, mononuclear cells infiltration, and hepatocyte apoptosis were occasionally found around the hepatic sinusoid in $1000 \mathrm{mg} / \mathrm{kg}$ MHTA treated group (Fig. 3A3). In kidney, the lowest dose group revealed no detectable abnormalities (Fig. 3B1-B2), while different degrees of hyperemia in glomerulus, inflammatory cell infiltration in renal tubular epithelial cell, and the narrowed and occlusive renal tubular were observed in mice of the highest dose (Fig. 3B3). Spleen showed normal red and white pulp as well as normal capsules in mice of the control and lowest dose group (Fig. 3C1-C2), while some focal necrosis and nuclear aggregations were observed in mice of the highest dose (Fig. 3C3). In heart, myocardium cell showed cross-over between muscle fibers in both the lowest dose and control group (Fig. 3D1-D2), while those cells exhibited nuclear aggregations and hypertrophy, and even myocardium cell apoptosis in the highest group (Fig. 3D3). In lung, all the experimental groups showed the same pattern of several alveolar air spaces separated by relatively thin alveolar septa (Fig. 3E1-E3), and no alteration was detected. Gross anatomical examinations on the ovary and testis showed no pathological lesions.

\subsection{Structural Characterization of Compounds}

In order to provide the information of chemical investigations, a phytochemistry investigation of MHTA were performed. A total of 15 TIAs were isolated by a series of column chromatographic separations and purification via MPLC, Pre-HPLC, and sephadex LH-20 (Fig. 4). Their structures were determined by the comprehensive analysis of ${ }^{1} \mathrm{H}$ NMR, ${ }^{13} \mathrm{C}$ NMR and HRESIMS spectroscopic data $\left({ }^{13} \mathrm{C}\right.$ NMR data in Table 5, $1 \mathrm{H}$ NMRand HRESIMS data were not shown). When compared with the reported data in the literatures, the isolated pure compounds were elucidated as melodinines A-C (1-3) [19], tabersonine (4) [20], 11-hydroxytabersonine (5) [21], 11-methoxytabersonine (6) [22], lochnericine (7) [22], kopsinine (8) [23], tubotaiwine (9) [24], (-)-eburnamenine (10) [25], $O$-methylepivincanol (11) [25], scandine (12) [26], 10-hydroxyscandine (13) [27], melaxilline A (14) [28], meloscandonine (15) [29].

\section{Discussion}

People also depend on traditional herbal medicine to treat diseases in developing countries [30]. Plants are invaluable sources of pharmaceutical agents [31], especially alkaloids [32]. M. henryi has been proved to be a good source of TIAs and has been used as a folk medicine for the treatment of some inflammatory diseases. Previous investigations on $M$. henryi are mainly focused on the isolation of TIAs with novel structures, evaluation of their cytotoxic activities on the human cancer cell lines. However, the researches on the anti-inflammatory potentials of the bioactive extract, and their phytochemicals have not been exploited. In this paper, $M$. henryi was extracted by methanol to obtain the crude extract (CE), and then processed to yield the non-alkaloidal extract (MHNA) and total alkaloidal extract (MHTA). We firstly reported the anti-inflammatory and immunosuppressive activities of $M$. henryi. The result showed that MHTA had the strongest anti-inflammatory and immunosuppressive activity than CE and MHNA. 


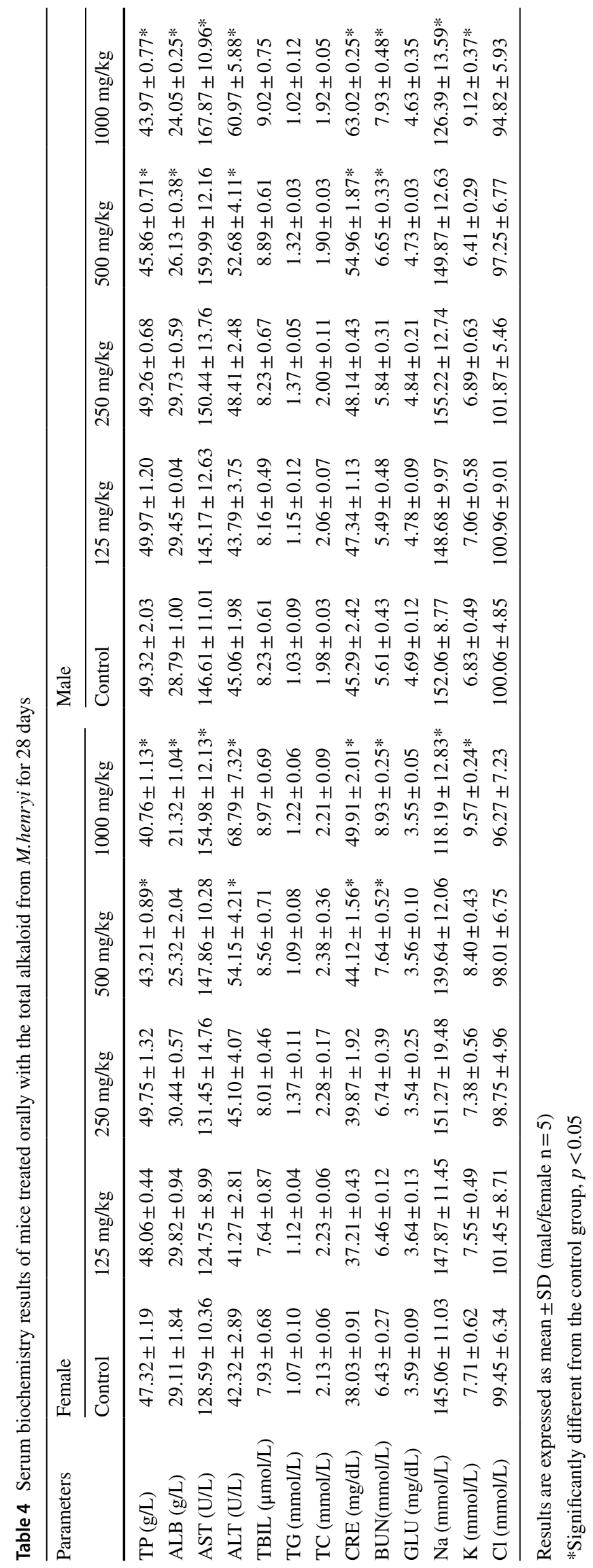


Fig. 3 Histopathological results of seven organs in mice after oral administration for 28 days. Liver: A1 (Control); A2 (125 mg/kg of MHTA); A3 (1000 mg/kg of MHTA). Kidney: B1 (Control); B2 (125 mg/ $\mathrm{kg}$ of MHTA); B3 (1000 mg/ $\mathrm{kg}$ of MHTA). Spleen: C1 (Control); $\mathrm{C} 2$ (125 mg/kg of MHTA); C3 (1000 mg/kg of MHTA). Heart: D1 (Control); D2 (125 mg/kg of MHTA); D3 (1000 mg/kg of MHTA). Lung: E1 (Control); E2 (125 mg/kg of MHTA); E3 (1000 mg/kg of MHTA). Testis: F1 (Control); F2 (125 mg/kg of MHTA); F3 (1000 mg/kg of MHTA). Ovary: G1 (Control); G2 (125 mg/ $\mathrm{kg}$ of MHTA); G3 (1000 mg/ $\mathrm{kg}$ of MHTA). All tissues were stained with H\&E $(200 \times)$
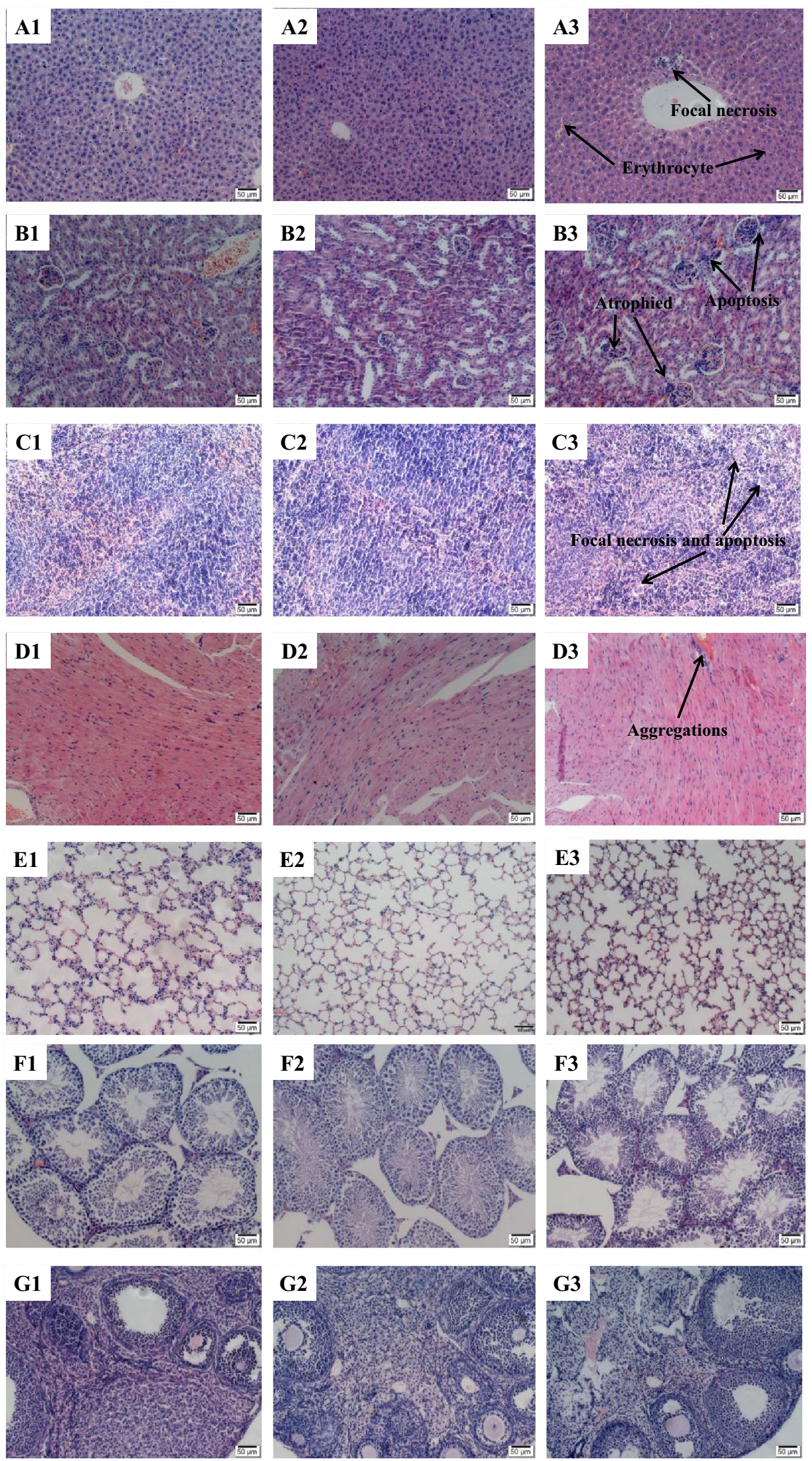
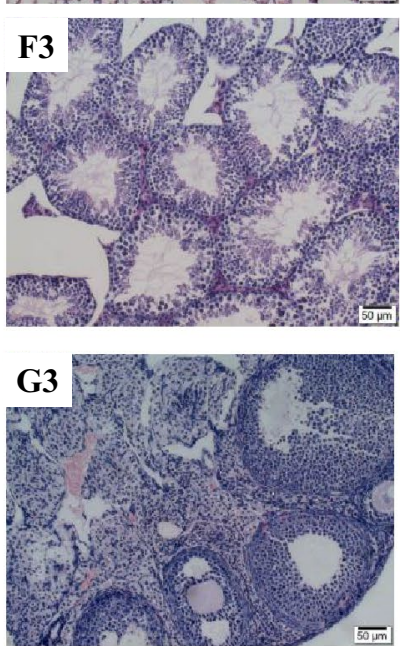
<smiles>[R]c1cc2c3n(c1=O)-c1ccccc1C31CCN3CC(CC)C(C2)C31</smiles>

$1 \mathrm{R}=\mathrm{CONH}_{2}$ $2 \mathrm{R}=\mathrm{COOCH}_{3}$ $3 \mathrm{R}=\mathrm{COOH}$<smiles>[R]C1C[C@]2(CC)CCCN3CCc4c(n1c1ccccc41)C32</smiles>

$10 \mathrm{R}=\mathrm{H}$ $11 \mathrm{R}=\mathrm{OCH}_{3}$<smiles>[R]c1ccc2c(c1)NC1=C(C(=O)OC)C[C@@]3(CC)CCCN4CC[C@@]12[C@H]43</smiles>

$4 \mathrm{R}=\mathrm{H} \quad \Delta^{14,15}$

$5 \mathrm{R}=\mathrm{OH} \quad \Delta^{14,15}$

$6 \mathrm{R}=\mathrm{OMe} \quad \Delta^{14,15}$

7 R=H 14,15- $\alpha$-epoxy<smiles>[R]c1ccc2c(c1)[C@@]1(CCN3CC=C[C@H](C=C)[C@H]3C1)C(=O)N2</smiles>

$12 \mathrm{R}=\mathrm{H}$ $13 \mathrm{R}=\mathrm{OH}$

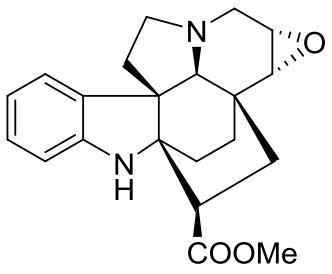

8<smiles>CC(=O)CC(C)C1C[C@H]2C(=O)Nc3ccccc3[C@]23CCN2CC=C[C@H]1[C@H]23</smiles>

14<smiles>CC(=O)C1=C2Nc3ccccc3C23CCN2CC1CC23</smiles>

9

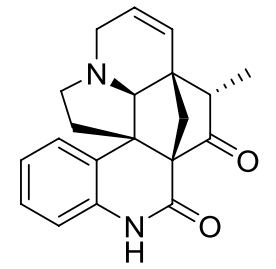

15

Fig. 4 Chemical structures of compounds 1-15

In order to provide the information of MHTA for the treatment of disease, the preclinical safety assessment is necessary to performed. The acute toxicity test was initially performed in mice of females due to the higher sensitivity than males, as it provides data to guide the other toxicity tests [32]. There were no significant changes in clinical signs, body weight gain, and food and water intakes in any female mice treated with $2000 \mathrm{mg} / \mathrm{kg}$ MHTA. The organs did not show any abnormality in their gross pathology examination. Therefore, the $\mathrm{LD}_{50}$ of the MHTA can be considered greater than $2000 \mathrm{mg} / \mathrm{kg}$, which was regarded as practically low toxic.

In the sub-acute toxicity experiments, the decreases of food consumption and water intake were observed in the dose of $1000 \mathrm{mg} / \mathrm{kg}$ during the experiment period $(p<0.05)$. The body weight of all animals in the $1000 \mathrm{mg} / \mathrm{kg}$ group was significantly lower compared to the control $(p<0.05)$, meaning that high dose of MHTA may be toxic to mice. The organ coefficient is a crucial detection index in the evaluation of drug safety, and provides a quantitative reference for drug evaluation. When the relative organ weights significantly changes, some underlying disease or damage (congestion, edema, or hypertrophy) may happen [33]. In this study, the relative weights of the liver in mice of $1000 \mathrm{mg} /$ $\mathrm{kg}$ group were significantly higher than that in mice of the control group $(p<0.05)$, suggesting that doses of $1000 \mathrm{mg} /$ $\mathrm{kg}$ MHTA might induce liver damage. The liver played a key role in the biotransformation, detoxification, and synthesis of serum proteins [34]. To further clarify whether MHTA has toxic effects on the liver or other organs, the hematological, serum biochemical and histopathological parameters were investigated.

The hematological parameters could provide direct evidence for toxicity assessment in humans and animals [35]. The significant increases of WBC $(p<0.05)$ in 500 and $1000 \mathrm{mg} / \mathrm{kg}$ groups were most likely induced by the body inflammation, which could be partly confirmed by the significant increases of LYM and MON. RBC and HGB levels were also significantly decreased at high doses of MHTA, and was in agreement with the previously reported damages in spleen [36]. In addition, PLT was significantly increased in the high dose group (500 and $1000 \mathrm{mg} / \mathrm{kg}$ ) $(\mathrm{p}<0.05)$, while GRA was slightly decreased, indicating that the reduction of granulocytes led to the suppression of immune function [33]. Pervious study had showed that the exposure to pyrrolizidine alkaloid resulted to hematopoietic disfunction or erythrocyte destruction [37]. Therefore, the MHTA-induces spleen damage mechanism may be similar to that of pyrrolizidine alkaloid. Meanwhile, the activity of adrenocortical hormone may initiate negative feedback regulation, thereby inhibit the productions of red blood cells and hemoglobin [38]. Moreover, a significant increase of PCT in $1000 \mathrm{mg} / \mathrm{kg}$ group (both male and female) may be caused by the increase of PLT, which is consistent with the reported results [39]. Daily oral administration of MHTA at high concentration for 28 days may affect the glucocorticoid hyperactivity, and lead to liver damage.

In the analysis of biochemical indicators, the TP, composed of ALB and GLB, in the groups of 500 and $1000 \mathrm{mg} /$ $\mathrm{kg}$ decreased significantly $(p<0.05)$, suggesting that the 
Table 5 C NMR spectroscopic data of compounds 1-15 ( $\delta$ in ppm)

\begin{tabular}{|c|c|c|c|c|c|c|c|c|c|c|c|c|c|c|c|}
\hline $\mathrm{NO}^{\mathrm{b}}$ & 1 & 2 & 3 & 4 & 5 & 6 & 7 & 8 & 9 & 10 & 11 & 12 & 13 & 14 & 15 \\
\hline 2 & 161.2 & 158.7 & 162.0 & 166.8 & 167.6 & 167.2 & 167.7 & 67.0 & 170.5 & 130.2 & 131.3 & 169.2 & 167.3 & 172.2 & 168.9 \\
\hline 3 & 62.2 & 60.0 & 62.1 & 50.6 & 50.9 & 50.5 & 50.1 & 48.0 & 45.1 & 45.4 & 45.6 & 47.7 & 47.8 & 44.7 & 47.1 \\
\hline 5 & 54.5 & 53.6 & 54.3 & 50.9 & 50.5 & 50.8 & 50.6 & 49.3 & 53.8 & 52.1 & 52.3 & 53.3 & 53.2 & 52.9 & 55.0 \\
\hline 6 & 44.9 & 46.2 & 44.6 & 44.5 & 44.4 & 44.5 & 44.7 & 36.2 & 43.8 & 16.6 & 17.6 & 39.9 & 41.0 & 39.6 & 40.3 \\
\hline 7 & 55.6 & 56.6 & 55.6 & 55.1 & 54.5 & 54.4 & 54.8 & 55.9 & 55.0 & 107.1 & 106.2 & 57.7 & 57.6 & 58.1 & 56.8 \\
\hline 8 & 140.1 & 139.4 & 139.6 & 138.0 & 129.8 & 130.4 & 137.5 & 139.1 & 137.0 & 128.3 & 130.0 & 128.9 & 127.9 & 126.2 & 130.3 \\
\hline 9 & 120.1 & 120.3 & 120.5 & 121.4 & 122.1 & 121.7 & 121.4 & 121.2 & 119.6 & 118.5 & 118.9 & 127.0 & 114.3 & 127.8 & 123.6 \\
\hline 10 & 126.9 & 126.7 & 128.0 & 120.6 & 107.2 & 105.0 & 120.7 & 119.3 & 121.0 & 119.8 & 121.0 & 123.7 & 153.0 & 124.3 & 123.9 \\
\hline 11 & 128.1 & 128.6 & 128.6 & 127.6 & 156.4 & 159.9 & 127.7 & 126.9 & 127.2 & 121.5 & 122.2 & 127.5 & 115.8 & 127.7 & 127.9 \\
\hline 12 & 117.4 & 118.2 & 117.9 & 109.3 & 97.7 & 96.7 & 109.4 & 111.1 & 109.7 & 108.5 & 111.9 & 115.5 & 113.9 & 115.8 & 116.2 \\
\hline 13 & 140.7 & 140.8 & 139.7 & $143.2 \mathrm{~s}$ & $144.2 \mathrm{~s}$ & $144.3 \mathrm{~s}$ & 142.9 & 149.1 & 143.6 & 133.5 & 137.2 & 134.2 & 130.0 & 135.0 & 136.6 \\
\hline 14 & 31.4 & 30.9 & 30.9 & 124.8 & 124.7 & 124.8 & 53.9 & 53.6 & 28.3 & 20.8 & 21.6 & 122.9 & 123.4 & 129.1 & 125.8 \\
\hline 15 & 36.3 & 33.8 & 36.1 & 133.1 & 133.0 & 133.0 & 57.2 & 58.0 & 30.8 & 27.5 & 26.6 & 131.4 & 131.2 & 132.2 & 128.1 \\
\hline 16 & 115.7 & 118.7 & 117.3 & 92.1 & 92.1 & 92.2 & 90.6 & 43.3 & 95.6 & 119.7 & 84.1 & 63.7 & 63.7 & 48.6 & 67.8 \\
\hline 17 & 145.4 & 143.9 & 146.4 & 26.9 & 28.3 & 26.8 & 23.2 & 26.8 & 11.5 & 116.7 & 35.7 & 44.1 & 44.3 & 41.9 & 38.4 \\
\hline 18 & 11.5 & 12.8 & 11.4 & 7.49 & 7.5 & 7.4 & 7.2 & 33.8 & 23.8 & 9.0 & 7.9 & 114.6 & 113.8 & 12.8 & 8.5 \\
\hline 19 & 26.5 & 27.6 & 26.3 & 28.4 & 26.9 & 28.3 & 24.3 & 27.6 & 41.1 & 31.1 & 29.8 & 142.2 & 142.4 & 47.6 & 52.7 \\
\hline 20 & 38.7 & 122.8 & 38.3 & 41.3 & 41.3 & 41.3 & 41.0 & 35.9 & 65.4 & 37.3 & 35.9 & 46.6 & 47.2 & 45.8 & 45.5 \\
\hline 21 & 51.5 & 129.9 & 51.2 & 70.0 & 70.2 & 70.1 & 67.5 & 61.6 & 72.8 & 55.8 & 60.4 & 83.6 & 84.3 & 75.8 & 61.6 \\
\hline 22 & 161.6 & 159.5 & 163.3 & - & - & - & - & - & - & - & - & - & - & - & - \\
\hline 23 & 120.2 & 119.4 & 117.1 & - & - & - & - & - & - & - & - & - & - & - & - \\
\hline $\mathrm{CO}_{2} \mathrm{NH}_{2}$ & 165.7 & - & - & - & - & - & - & - & - & - & - & - & - & - & - \\
\hline $\mathrm{CO}_{2} \mathrm{Me}$ & - & 166.1 & - & 169.0 & 169.4 & 169.0 & 168.8 & 174.1 & 168.8 & - & - & 170.4 & 170.6 & 174.6 & - \\
\hline $\mathrm{CO}_{2} \mathrm{Me}$ & - & 52.3 & - & 51.0 & 51.3 & 51.0 & 51.1 & 52.0 & 51.1 & - & - & 52.6 & 51.6 & 51.4 & - \\
\hline $\mathrm{CO}_{2} \mathrm{H}$ & - & - & 165.5 & - & - & - & - & - & - & - & - & - & - & - & - \\
\hline $\mathrm{CO}$ & - & - & - & - & - & - & - & - & - & - & - & - & - & - & 209.5 \\
\hline OMe & - & - & - & - & - & 55.4 & - & - & - & - & 55.8 & - & - & - & - \\
\hline
\end{tabular}

Data were measured at $150 \mathrm{MHz}$ for ${ }^{13} \mathrm{C}$ NMR.

${ }^{\mathrm{a}} \mathrm{All}$ compounds were measured in $\mathrm{CDCl}_{3}$

ability of protein synthesis may be reduced. ALB shows a downward trend, suggesting the rise of GLB in the 500 and $1000 \mathrm{mg} / \mathrm{kg}$ groups. The increase of GLB is a sign of activation of the immune system, indicating the occurrence of inflammation in the body [40], which was consistent with the predicted increases of WBC and LYM levels.

The liver is the main organ responsible for natural products metabolism and increased indicative activities of serum enzymes AST and ALT are considered sensitive markers of hepatocellular damage [41]. Higher levels of AST and ALT were observed in higher dose group compared to the control $(p<0.05)$, indicating that high doses of MHTA might damage the liver. The observed increase in the relative liver organ weight and reduction of RBC confirmed this assumption, which was consistent with the reported result [42]. The kidney is another sensitive organ exposed to toxic compounds. CRE and BUN are known as effective indicators for assessing kidney injury [43]. The levels of CRE and BUN in the 500 and $1000 \mathrm{mg} / \mathrm{kg}$ MHTA groups significantly increased than those in the control group $(p<0.05)$. Meanwhile, the content of sodium ions significantly decreased, while the content of potassium ions significantly increased in the highest dose group, indicating that the kidney was damaged and glomerular filtration function injury resulted in the impairment of ion balance in the blood [40]. This finding was further confirmed by histopathological observations of the kidney tissue in this study.

Biochemical data of high concentrations of MHTA revealed side effects to vital organs in mice, the histopathological studies provide a supportive evidence for hematological and biochemical analysis. The histopathology changes mainly occurred in the liver, kidney, spleen, and heart at high doses of MHTA $(1000 \mathrm{mg} / \mathrm{kg})$. Meanwhile, the severity of the dose is related to increased treatment duration, suggesting accumulative toxic effect of the alkaloids.

Furthermore, there is an urgent need for phytochemical investigation on bioactive ingredients of this plant to understand the chemical components of MHTA. Phytochemical 
research showed that about 66 alkaloids of different structures have been isolated from $M$. henryi so far $[8,12-14$, 19]. In this study, 15 monoterpenoid indole alkaloids were isolated and identified. According to the structural characteristics, the compounds were classified as strychnos-type alkaloids (1-3), aspidosperma-type alkaloids (4-8), condylocarpan-type alkaloid (9), eburna-type alkaloids (10-11), and quinoline-type alkaloids (12-15).

Previous reports on the cytotoxic activities of the compounds showed that aspidosperma-type alkaloids 4, 5, 6 and $\mathbf{8}$ had significant cytotoxic activities on human cancer cell lines, while other types of compounds have no obvious cytotoxic activity $[13,19]$. Therefore, the chemical constituents and contents of aspidosperma-type alkaloids may be related to the toxicity of MHTA. Besides, some quinoline and indole alkaloids isolated from Melodinus plants, such as 15-dihydroscandine, $15 \beta$-hydroxy-14,15-dihydroscandine, melaxillines $\mathrm{A}$ and $\mathrm{B}$, melodinine $\mathrm{T}$, scandine, 11-hydroxytabersonine, and $O$-methyl- $\Delta^{14}$-vincanol-3-one exhibited significant anti-inflammatory activity [17, 28, 44, 45]. Among the isolates in this study, tabersonine (4) could attenuate LPSinduced acute lung injury and inhibited LPS-mediated macrophage activation in vitro [46], 11-hydroxytabersonine (5) showed inhibitory effect on NO production [17], tubotaiwine (9) showed good inhibitions on COX-1 and COX-2 in anti-inflammatory assay in vitro [47], and melaxilline A (14), scandine (12), and meloscandonine (15) significantly inhibited in release of $\beta$-glucuronidase [28], suggesting these compounds may be responsible for the anti-inflammatory effect of MHTA.

As we all known, the combined effects (such as synergistic effect, additive effect, antagonistic effect) in the mixture of compounds are exist in bioactivity evaluation [48], and the compounds might be absorbed, distributed, metabolized and excreted in the animal body. Whether there are some combined effects of the molecules for the toxicity and the bioactive potential still needs to be further studied.

\section{Conclusions}

In the present study, we firstly performed the anti-inflammatory and immunosuppressive activities of $M$. henryi to fill its gap in the traditional applications. MHTA showed the strongest anti-inflammatory and immunosuppressive activities than CE and MHNA. In order to obtain the safety information of MHTA in the treatment of inflammatory diseases, the acute and sub-acute toxicity evaluations were conducted in animal models. It did not display any abnormal behaviors and mortality when administered in a single dose of $2000 \mathrm{mg} / \mathrm{kg}$. However, the repeated administration of subacute toxicity experiment, MHTA (greater than $500 \mathrm{mg} / \mathrm{kg}$ ) might selectively damage the organ tissues, such as kidney, heart, liver, and spleen, suggesting caution is required for the use. In addition, 15 pure TIAs were also isolated and further performed as standards for the control of the MHTA quality. Therefore, the present work provides deeper knowledge about the species $M$. henryi, expands the applications of the MHTA on the inflammatory diseases under a safe dose as a quality controllable drug candidate.

\section{Materials and Methods}

\subsection{Samples}

The aerial part of $M$. henryi $(10 \mathrm{~kg})$ was collected from Jinghong of China (GPS: $21^{\circ} 32^{\prime} \mathrm{N} / 100^{\circ} 28^{\prime} \mathrm{E}$ ) in October 2017, and identified by Dr. Y.P. Liu, Kumming Institute of Botany, CAS. A voucher specimen (No. Cheng20171008-03) was stored in the cool and dry environment of the faculty of agriculture and food, Kunming University of science and technology.

\subsection{Extraction and Preparation of Sample}

The sample was cut into pieces, powdered and extracted with $90 \%$ aqueous $\mathrm{CH}_{3} \mathrm{OH}$ for three times ( $48 \mathrm{~h}$ at a time). The extract solvent was collected and then concentrated under vacuum to obtain a crude extract (CE). The residue was dissolved in acidic aqueous solvent including $0.3 \%$ hydrochloric acid (v/v) and partitioned with EtOAc (1:1, v/v) for three times. The acidic aqueous solution was adjusted with $5 \%$ ammonia to have a $\mathrm{pH}$ value about 9-10. The alkaline aqueous solution was then partitioned with EtOAc (1:1, v/v) for three times. After collection and concentration of EtOAc solvent, the total alkaloidal extract was obtained (MHTA). The remaining part was evaporated under reduced pressure at $50{ }^{\circ} \mathrm{C}$ to obtain the non-alkaloid extract (MHNA).

\subsection{Anti-Inflammatory Assay}

RAW264.7 macrophages were purchased from Kunming cell bank, CAS, and were cultured in DMEM with $10 \%$ fetal bovine serum (FBS) and $1 \%$ antibiotics $(100 \mathrm{U} / \mathrm{mL}$ penicillin and $100 \mu \mathrm{g} / \mathrm{mL}$ streptomycin) under a humidified atmosphere containing $5 \% \mathrm{CO}_{2}$ at $37{ }^{\circ} \mathrm{C}$.

Cytotoxicity of CE, MHTA and MHNA on RAW264.7 macrophage cells was performed by MTT assay [49]. Then the anti-inflammatory effect was assessed under non-toxic concentrations. In brief, after $2 \mathrm{~h}$ treatment with the test sample, LPS was added into the RAW264.7 cells with a concentration of $1.0 \mu \mathrm{g} / \mathrm{mL}$, and the cells were cultured for $22 \mathrm{~h}$. Then the content of $\mathrm{NO}$ was determined by the instruction of nitric oxide (NO) assay kit (Nitrate reductase method). And the TNF- $\alpha$ and IL-6 levels in the supernatants were 
measured by ELISA kits (MultiSciences (Lianke) Biotech, Hangzhou, China).

\subsection{Splenocyte Proliferation Assay}

A previously reported CCK-8 method was used to carry out the immunosuppressive activity [50]. In brief, splencoytes isolated from male BALb/c mice were seeded into 96-well flat-bottom microtiter plates at a density of $1 \times 10^{6} \mathrm{cell} / \mathrm{mL}$. Then cells were exposed to the test samples in the presence of concanavalin A (Con A) and lipopolysaccharides (LPS), respectively, using the Con A-/LPS-treated splenocytes as the experimental control, dexamethasone (DXM) as positive control. After incubation for $44 \mathrm{~h}, 10 \mu \mathrm{L}$ of CCK- 8 was added and incubated for another $4 \mathrm{~h}$ and the absorbance was measured at $450 \mathrm{~nm}$ by using a microplate reader (SpectraMax M5, Molecular Device, USA). Finally, the inhibitory effects of different sample were analyzed.

\subsection{Toxicological Evaluations}

\subsubsection{Animals}

Sixty mice ( 45 females and 25 males) weighing between 18 and $22 \mathrm{~g}$ provided by Kunming Medical University (SYXK, 2011-0004) were used. The animals were acclimated in a specificpathogen free (SPF) laboratory $(12 \mathrm{~h} / 12 \mathrm{~h}$ of dark-light cycle, temperature of $24 \pm 2^{\circ} \mathrm{C}$, relative humidity of $40-70 \%$ ), and fed a basic animal feed (5\% fiber, $5 \%$ fat, $20 \%$ protein, $60 \%$ carbohydrate) for 7 days. The toxicological evaluations were conducted according to the recommendations from the National Institutes of Health Guide for Laboratory Animal Care and Use.

\subsubsection{Acute Toxicity Evaluation}

Twenty female mice were used to evaluate the acute toxicity study due to the OECD423 guideline [34]. The animalswere randomly grouped into control, 300, 1000, and $2000 \mathrm{mg} / \mathrm{kg}$ experimental groups $(\mathrm{n}=5)$. The MHTA was dissolved in distilled water, and then the animal was given orally in MHTA groups, while the control group was given the medium. After administration, the general behavioral changes (i.e. altered locomotion, breathing difficulty, tremors, lethargy and convulsion) and mortality were observed at $0.5 \mathrm{~h}, 2 \mathrm{~h}, 4 \mathrm{~h}, 6 \mathrm{~h}, 10 \mathrm{~h}$, and $24 \mathrm{~h}$ for the first day, and then recorded daily for 14 days [51]. Body weight, food and water intakes were assessedat the 4th, 7th, 11th and 14th day, and then weekly changes were calculated. The median lethal dose $\left(\mathrm{LD}_{50}\right)$ was assessed under the principle of "Acute Toxic Class Method".

\subsubsection{Sub-Acute Toxicity Evaluation}

The sub-acute toxicity experiment was performed in mice ( 25 females and 25 males) according to the OECD guideline [52]. The mice were randomly divide into 5 groups including the control group and four MHTA intervention groups (125, 250,500 and $1000 \mathrm{mg} / \mathrm{kg}$, respectively) with 5 males and 5 females per group. Each animal was administered by oral gavage daily for 28 days. The mortality and abnormal behaviors were recorded every day. Body weights, food and water intakes were assessed once a week. The mice were given a certain amount of food (water), and the amount of remaining food (water) was measured at the same time in the next day. The food (water) consumption was calculated by the difference. After 4 week of MHTA administration, all animals were anaesthetized with chloral hydrate and sacrificed by cervical dislocation. Blood was drawn in tubes containing EDTA for biochemistry and hematology assessments. The body organs (lung, spleen, heart, kidney, liver, ovary and testis) were harvested for organ index calculations, and further histo-pathological analyses.

\subsubsection{Hematological Analysis}

The hematological parameters, including percentage of lymphocytes (LYM\%), lymphocyte (LYM), red blood cell (RBC), red blood cell volume (HCT), white blood cell (WBC), monocytes (MON), mean corpuscular hemoglobin $(\mathrm{MCH})$, percentage of granulocytes (GRA\%), mean platelet volume (MPV), mean corpuscular volume (MCV), platelet (PLT), hemoglobin (HGB), and platelet pressure (PCT) were detected by an automatic blood cell analyzer HF-3800 Plus (Hanfang Ltd., Jinan, China).

\subsubsection{Biochemical Analysis}

The blood samples were centrifuged at $4000 \mathrm{rpm}$ for $10 \mathrm{~min}$ at $4{ }^{\circ} \mathrm{C}$ for biochemical analysis. The serum biochemical parameters, including aminotransferase (ALT), aspartate transaminase (AST), total protein (TP), albumin (ALB), triglycerides (TG), total cholesterol (TC), total bilirubin (TBIL), glucose (GLU), alanine blood urea nitrogen (BUN), creatinine (CRE), potassium $(\mathrm{K})$, sodium $(\mathrm{Na})$, and chloridne $(\mathrm{Cl})$ were analyzed by using commercial kits (Nanjing Jiancheng Biological Product, China).

\subsubsection{Histological Analysis}

The tissues (lung, kidney, heart, spleen, liver, ovary, and testis) were collected, and weighed to calculate organ coefficients [40]. All tissues were fixed in 10\% buffered formalin for further hematoxylin-eosin (H\&E) assessment. Then, the 
tissue sections were detected and analyzed for cellular damage or change under microscope.

\subsection{Isolation and Purification}

The crude alkaloidal extract (98.0 g) was separated on a RP- $\mathrm{C}_{18}$ MPLC column with a gradient solvent $\mathrm{MeOH} / \mathrm{H}_{2} \mathrm{O}$ (from 20:80 to 100:0) to afford six fractions (A-F). Fraction A (2.6 g) was isolated on a silica gel column (30:1) with petroleum ether-acetone (v/v, 10:1, 5:1 and 3:1) and then purified by Sephadex LH-20 (MeOH) column and a preparative HPLC $\left(\mathrm{CH}_{3} \mathrm{CN} / \mathrm{H}_{2} \mathrm{O}: 50: 50\right)$ to yield compound $4(9.2 \mathrm{mg})$ and $5(28.7 \mathrm{mg}) \mathbf{7}(4 \mathrm{mg}), \mathbf{8}(13.6 \mathrm{mg})$, and $10(28.4 \mathrm{mg})$. Fr.B $(9.7 \mathrm{~g})$ was chromatographed by MPLC $\left(\mathrm{MeOH} / \mathrm{H}_{2} \mathrm{O}, 30: 70-70: 30\right)$ to yield three subfractions (B1-B3). Compounds $2(33 \mathrm{mg})$ and $\mathbf{6}(19.6 \mathrm{mg})$ were obtained from sbufraction B-3 (203 mg) by a preparative HPLC purification $\left(\mathrm{CH}_{3} \mathrm{CN} / \mathrm{H}_{2} \mathrm{O}, 40: 60\right)$. $\mathrm{Fr} . \mathrm{C}(7.7 \mathrm{~g})$ was separated by MPLC $\left(\mathrm{CH}_{3} \mathrm{OH} / \mathrm{H}_{2} \mathrm{O}, 30: 70-70: 30\right)$ and further purified by silica gel column using a petroleum etheracetone (3:1) to give compounds $\mathbf{1}(15 \mathrm{mg}), \mathbf{1 3}(17 \mathrm{mg})$ and $11(29 \mathrm{mg})$. Fr.D $(2.6 \mathrm{~g})$ was separated by MPLC with $\mathrm{CH}_{3} \mathrm{OH} / \mathrm{H}_{2} \mathrm{O}$ (30:70-50:50) and further resolved by HPLC withCH $\mathrm{H}_{3} \mathrm{OH} / \mathrm{H}_{2} \mathrm{O}$ (50:50) to yield compounds $3(28 \mathrm{mg}$ ), and $14(3.6 \mathrm{mg})$. Fr.E $(6.3 \mathrm{~g})$ was separated by MPLC with $\mathrm{CH}_{3} \mathrm{OH} / \mathrm{H}_{2} \mathrm{O}$ (20:80-60:40) to get compound 9 (2.9 mg) and $12(21.2 \mathrm{mg})$. Fr.F (30 g) was separated by MPLC with $\mathrm{CH}_{3} \mathrm{OH} / \mathrm{H}_{2} \mathrm{O}$ (20:80-50:50) and purified by a silica gel column $\left(\mathrm{CHCl}_{3}: \mathrm{MeOH}, 10: 1\right)$ to afford compound $\mathbf{1 5}(8.8 \mathrm{mg})$.

\subsection{Statistical Analysis}

All tests were carried out in triplicate and data were expressed as mean \pm SD (standard deviation). Statistical analysis was performed with one-way analysis of variance (ANOVA). Statistical significance of differences between the groups was assessed using the Student's t-test. The $p<0.05$ was considered significant.

Acknowledgments This research was supported by the open program of State Key of Phytochemistry and Plant Resources in West China (P2018-KF08), the Applied Basic Research Project of Yunnan Province (Grant numbers No. 2018FB036 and 2017FD121), the National Natural Science Foundation of China (Grant Numbers 31600274).

\section{Compliance with Ethical Standards}

Conflict of interest All authors declare that they have no conflict of interest.

Open Access This article is licensed under a Creative Commons Attribution 4.0 International License, which permits use, sharing, adaptation, distribution and reproduction in any medium or format, as long as you give appropriate credit to the original author(s) and the source, provide a link to the Creative Commons licence, and indicate if changes were made. The images or other third party material in this article are included in the article's Creative Commons licence, unless indicated otherwise in a credit line to the material. If material is not included in the article's Creative Commons licence and your intended use is not permitted by statutory regulation or exceeds the permitted use, you will need to obtain permission directly from the copyright holder. To view a copy of this licence, visit http://creativecommons.org/licenses/by/4.0/.

\section{References}

1. G.P. Choudhary, A.P. Jain, Int. J. Pharm. Pharm. Res. 7, 175-184 (2016)

2. D.J. Newman, G.M. Cragg, J. Nat. Prod. 79, 629-661 (2016)

3. S.S. Bharate, M. Serge, R.A. Vishwakarma, J. Med. Chem. 61, 10345-10374 (2018)

4. S.A. Khalifa, P. De Medina, A. Erlandsson, H.R. El-Seedi, S. Silvente-Poirot, M. Poirot, Biochem. Bioph. Res. Co. 446, 681-686 (2014)

5. S. Perviz, H. Khan, A. Pervaiz, Front. Pharmacol. 7, 28 (2016)

6. G.G. Cheng, D. Li, B. Hou, X.N. Li, L. Liu, Y.Y. Chen, P.K. Lunga, A. Khan, Y.P. Liu, Z.L. Zuo, X.D. Luo, J. Nat. Prod. 79, 2158-2166 (2016)

7. V. Amirkia, M. Heinrich, Phytochem. Lett. 10, xlviii-liii (2014)

8. J.H. Jiang, W.D. Zhang, Y.G. Chen, Trop. Pharm. Res. 14, 2325$2344(2015)$

9. Y. Tsiang, P.Y. Li, Flora of China, vol. 63 (Science Press, Beijing, 1977), p. 24

10. T. Feng, X.H. Cai, Y.P. Liu, Y. Li, Y.Y. Wang, X.D. Luo, J. Nat. Prod. 73, 2226 (2010)

11. Y.P. Liu, G.G.L. Yue, J.K.M. Lee, T. Feng, Y.L. Zhao, Y. Li, C.B.S. Lau, X.D. Luo, Bioorg. Med. Chem. Lett. 26, 4895-4898 (2016)

12. Q. Shao, R. Ma, X. Wu, F.L. Zhang, Z.H. Li, T. Feng, J. He, J.K. Liu, Phytochem. Lett. 35, 53-57 (2020)

13. J. He, F.L. Zhang, Z.H. Li, H.X. Yang, Q. Shao, T. Feng, J.K. Liu, Fitoterapia 138, 104354 (2019)

14. L.L. Guo, Y.X. Yuan, H.P. He, S.L. Li, Y. Zhang, X.J. Hao, Phytochem. Lett. 21, 179-182 (2017)

15. T. Feng, X.H. Cai, Y. Li, Y.Y. Wang, Y.P. Liu, M.J. Xie, X.D. Luo, Org. Lett. 11, 4834-4837 (2009)

16. Y.W. Zhang, R. Yang, Q. Cheng, K. Ofuji, Helv. Chim. Acta. 86, 415-419 (2003)

17. J.Q. Yu, X.W. Sun, Z.W. Wang, L. Fang, X. Wang, J. Asian Nat. Prod. Res. 21, 820-825 (2019)

18. Y.L. Zhao, X.W. Yang, B.F. Wu, J.H. Shang, Y.P. Liu, D. Zhi, X.D. Luo, J. Agr. Food Chem. 67, 8810-8818 (2019)

19. T. Feng, X.H. Cai, Y.P. Liu, Y. Li, Y.Y. Wang, X.D. Luo, J. Nat. Prod. 73, 22-26 (2010)

20. H. Mehri, M. Plat, P. Potier, Ann. Pharm. Fr. 29, 291-296 (1971)

21. H. Mehri, M. Koch, M. Plat, P. Potier, Ann. Pharm. Fr. 30, 643 650 (1972)

22. S. Baassou, H. Mehri, M. Plat, Phytochemistry 17, 1449-1450 (1978)

23. M. Kitajima, M. Anbe, N. Kogure, S. Wongseripipatana, H. Takayama, Tetrahedron 70, 9099-9106 (2014)

24. M. Pinar, H. Schmid, Justus. Liebigs. Ann. Chem. 668, 97-104 (1963)

25. B.T. Yang, L. Liu, M. Zhang, Y.P. Liu, B.C. Li, X.J. Qin, Nat. Prod. Res. Dev. 28, 868-873 (2016)

26. K. Bernauer, G. Englert, W. Vetter, E. Weiss, Helv. Chim. Acta. 52, 1886-1905 (1969)

27. Y.L. Zhou, J.H. Ye, Z.M. Li, Z.H. Huang, Planta Med. 54, 315317 (1988) 
28. L. Fang, S.M. Tian, J. Zhou, Y.L. Lin, Z.W. Wang, X. Wang, Fitoterapia 115, 173-176 (2016)

29. L.W. Guo, Y.L. Zhou, Phytochemistry 34, 563-566 (1993)

30. D.M. Turner, J. Ethnopharmacol. 51, 39-44 (1996)

31. H. Yuan, Q. Ma, L. Ye, G. Piao, Molecules 21, 559 (2016)

32. OECD, The OECD Guidelines for the testing of chemicals, Test No. 423: acute oral toxicity: acute toxic class method (OECD, Paris, 2001)

33. I.I. Ijeh, O. Obidoa, Niger. J. Biochem. Mol. Biol. 16, 50-51 (2001)

34. S.C. Udem, O. Obidoa, I.U. Asuzu, Comp. Clin. Pathol. 19, 275$282(2010)$

35. H. Rhiouani, J. Elhilaly, Z.H. Israili, B. Lyoussi, J. Ethnopharmacol. 118, 378-386 (2008)

36. Y. Chen, M.X. Wu, J. Liu, X.J. Ma, J.L. Shi, S.N. Wang, Z.Q. Zheng, J.Y. Guo, J. Ethnopharmacol. 213, 199-209 (2017)

37. R. Swick, P. Cheeke, C. Miranda, D. Buhler, J. Toxicol. Env. Heal. A. 10, 757-768 (1982)

38. R.H. Xin, W.J. Peng, X.L. Liu, Y.J. Luo, G.B. Wang, C.Y. Luo, J.S. Xie, J.Y. Li, G. Liang, J.F. Zheng, Afr. J. Tradit. Complem. Altern. Med. 13, 140-149 (2016)

39. M.L. Yang, Z.H. Wu, Y.D. Wang, G.Y. Kai, G.S.S. Njateng, S.B. Cai, J.X. Cao, G.G. Cheng, Food Chem. Toxicol. 131, 110534 (2019)

40. Z.H. Wu, Y.L. Ma, L. Zhao, S.B. Cai, G.G. Cheng, Food Chem. Toxicol. 119, 14-23 (2018)

41. S.Y. Hor, M. Ahmad, E. Farsi, C.P. Lim, M.Z. Asmawi, M.F. Yam, J. Ethnopharmacol. 137, 1067-1076 (2011)
42. R. Schoental, P.N. Magee, J. Pathol. Bacteriol. 78, 471-482 (1959)

43. R.D. Lima, C.G. Guex, A.R.H.D. Silva, C.L. Lhamas, K.L.D.S. Moreira, R. Casoti, R.C. Dornelles, M.L.D. Veiga, L.D.F. Bauermann, J. Ethnopharmacol. 224, 76-84 (2018)

44. J.H. Jiang, W.D. Zhang, Y.G. Chen, Trop. J. Pharm. Res. 14, 2325-2344 (2015)

45. J. Zhou, Z. Fang, P. Zhou, Y. Wang, L. Fang, H. Zhang, Phytochem. Lett. 33, 22-25 (2019)

46. D.P. Zhang, X.Z. Li, Y.D. Hu, H.C. Jiang, Y.X. Wu, Y.H. Ding, K.K. Yu, H.Q. He, J.S. Xu, L. Sun, F. Qian, Biochem. Pharmacol. 154, 183-192 (2018)

47. J.H. Shang, X.H. Cai, T. Feng, Y.L. Zhao, J.K. Wang, L.Y. Zhang, M. Yan, X.D. Luo, J. Ethnopharmacol. 129, 174-181 (2010)

48. H. Jiang, X. Shang, H. Wu, G. Huang, Y. Wang, S. Al-Holou, S.C. Gautam, M. Chopp, Neurochem. Res. 35, 152-161 (2010)

49. M.L. Yang, Y.L. Ma, Z.Y. Wang, A. Khan, W.B. Zhou, T.R. Zhao, J.X. Cao, G.G. Cheng, S.B. Cai, Ind Crop. Prod. 143, 111433 (2020)

50. Z.Y. Wang, M.J. Jiang, A. Khan, S.B. Cai, X.N. Li, J.Q. Liu, G.Y. Kai, T.R. Zhao, G.G. Cheng, J.X. Cao, Phytochemistry 168, 112127 (2019)

51. Y.L. Zhao, M. Su, J.H. Shang, X. Wang, G.S.S. Njateng, G.L. Bao, J. Ma, Q.D. Sun, F. Yuan, J.K. Wang, X.D. Luo, Nat. Prod. Bioprospect. 10, 77-88 (2020)

52. OECD, The OECD Guidelines for the testing of chemicals, Test No. 407: Repeated dose 28-day oral toxicity study in rodents (OECD, Paris, 2008) 